\title{
Chemical Compounds Recovery in Carboxymethyl Cellulose Wastewater Treatment
}

DOI: $10.15255 /$ KUI.2014.011

KUI-14/2015

Original scientific paper

Received March 18, 2014 Accepted September 24, 2014

\author{
P.-H. Rao, ${ }^{a}$ W.-Q. Zhang, ${ }^{a^{*}}$ W. Yao, ${ }^{a}$ A.-Y. Zhu, ${ }^{a}$ \\ J.-L. Xia, ${ }^{a}$ Y.-F. Tan, ${ }^{a}$ Y.-J. Li, ${ }^{a}$ and T.-Z. Liu ${ }^{\mathrm{b}}$ \\ a School of Chemistry and Chemical Engineering, Shanghai \\ University of Engineering Science, 201620 Shanghai, PR China \\ b Harbin Institute of Technology Shenzhen Graduate School, \\ 518055 Shenzhen, PR China
}

\begin{abstract}
\| Abstract
Carboxymethyl cellulose $(\mathrm{CMC})$ is a kind of cellulose ether widely used in industrial production. CMC wastewater usually have high chemical oxygen demand (COD) and salinity (>10\%), which result from organic and inorganic by-products during CMC production. It is significant that the wastewater is pretreated to decrease salinity and recover valuable organics before biochemical methods are employed. In this paper, distillation-extraction method was used to pretreat CMC wastewater and recover valuable chemical compounds from wastewater (Fig. 1). Initial pH of CMC wastewater was adjusted to different values $(6.5,8.5,9.5,10.5,12.0)$ before distillation to study the effect of $\mathrm{pH}$ on by-products in wastewater. By-products obtained from CMC wastewater were extracted and characterized by NMR, XRD and TGA. Distillate obtained from distillation of wastewater was treated using biological method, i.e., upflow anaerobic sludge blanket (UASB)-contact oxidation process. Domestic sewage and flushing water from manufacturing shop was added into distillate to decrease initial COD and increase nutrients such as $\mathrm{N}, \mathrm{P}, \mathrm{K}$.

Experimental results showed that by-products extracted from CMC wastewater mainly include ethoxyacetic acid and $\mathrm{NaCl}$, which were confirmed by NMR and XRD (Fig. 2). TGA results of by-products indicated that the content of $\mathrm{NaCl}$ in inorganic by-products reached $96 \%$. Increasing initial $\mathrm{pH}$ value of $\mathrm{CMC}$ wastewater might significantly raise the purity of ethoxyacetic acid in organic by-products. UASB-contact oxidation process showed a good resistance to shock loading. Results of 45-day continuous operation revealed that $\mathrm{COD}_{\mathrm{Cr}}$ of final effluent might be controlled below $500 \mathrm{mg} \mathrm{l}^{-1}$ and meet Shanghai Industrial Wastewater Discharge Standard $\left(\mathrm{COD}_{\mathrm{Cr}}<500 \mathrm{mgl}^{-1}\right)$, which indicated that the treatment process in this study was appropriate to treat distillate of wastewater from CMC production industry.
\end{abstract}

\section{\| Keywords}

Ethoxyacetic acid, carboxymethyl cellulose, wastewater treatment, recovery

\section{Introduction}

Cellulose ethers are widely used as gelation agents, thickeners, stabilizers, and emulsifiers in food industry as well as oil industry. These compounds include methyl cellulose (MC), hydroxypropyl cellulose (HPC), hydroxypropyl methyl cellulose (HPMC), and methyl ethyl cellulose (MEC). The most widely used cellulose compound is MC such as carboxymethyl cellulose (CMC) and its sodium salt (NaCMC). ${ }^{1-3}$

CMC is produced by etherification of the hydroxyl groups with sodium monochloroacetate (SMCA) in the presence of aqueous alkali. The method is based on Williamson's ether synthesis. ${ }^{4}$ The first step in the carboxymethylation is an equilibrium reaction between $\mathrm{NaOH}$ and the hydroxyl groups of the cellulose. The second step is actual formation of the carboxymethyl group by the substitution of SMCA.

\footnotetext{
${ }^{*}$ Corresponding author: Prof. Wenqi Zhang

e-mail: zhangwenqi_hit@163.com
}

The following steps are neutralization, purification and separation of CMC (Fig. 1).

Production of $\mathrm{CMC}$ is simpler than that of other cellulose ethers because all reactions are operated at atmospheric pressure using commercially available reagents. The etherifying reagent, sodium monochloroacetate, is easy to handle and very efficient. For these reasons, CMC has become the largest industrial cellulose ether. Large quantities of CMC are produced in crude commercial grades for use in detergents, oil drilling, and paper industry. High-purity grades are also employed as food additives. ${ }^{5}$ However, in the process of CMC production, SMCA can also react by an undesired pathway with $\mathrm{NaOH}$ to form by-products that may further react by polycondensation or other pathways.

Since large quantities of by-products form in the process of $\mathrm{CMC}$ production, $\mathrm{CMC}$ wastewater have high salinity and chemical oxygen demand (COD). It is usually necessary that the wastewater is pretreated using physical 


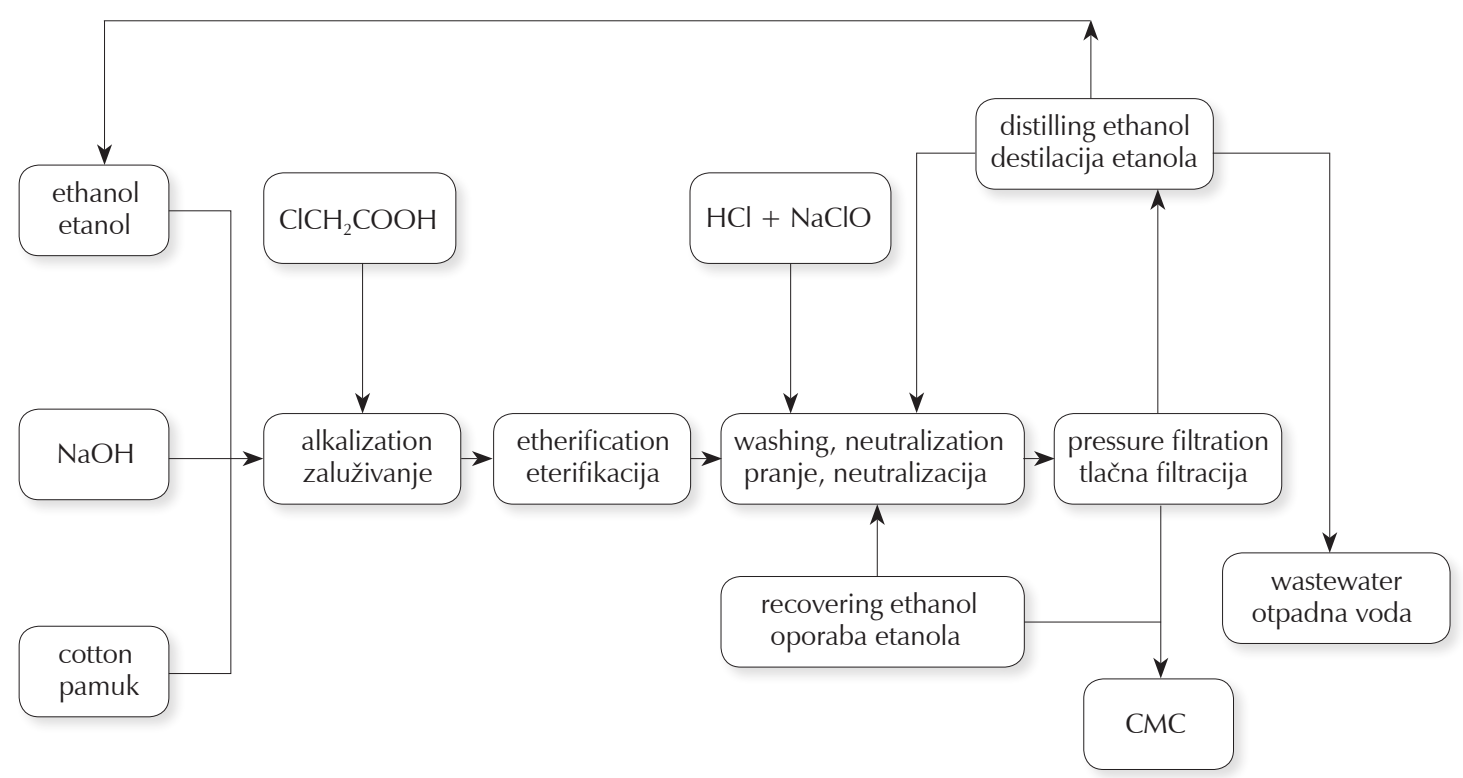

Fig. 1 - Carboxymethyl cellulose (CMC) production process

Slika 1 - Proizvodni proces karboksimetil-celuloze (CMC)

and/or chemical methods before biochemical methods are employed. ${ }^{6}$ Common physical and/or chemical methods include distillation, coagulation, membrane filtration, redox, electrochemical treatment, etc. ${ }^{7-11}$ A good pretreated method should not only decrease salinity of wastewater, but also recover valuable compounds from wastewater. However, to the best of our knowledge, the study on the compound recovery from CMC wastewater is rarely reported.

In this study, distillation-extraction method was used to pretreat CMC wastewater, and by-products in $\mathrm{CMC}$ wastewater were extracted and characterized by nuclear magnetic resonance (NMR), X-ray diffraction (XRD), and thermogravimetric analysis (TGA). Effects of initial pH value of CMC wastewater on the purity of by-products were studied. The distillate obtained from distillation of wastewater was treated using upflow anaerobic sludge blanket (UASB)-contact oxidation process to meet drainage standard of effluent.

\section{Experiments}

\section{Materials}

CMC wastewater with ethanol was supplied by Shanghai Changguang Co. Ltd. Other chemicals including $\mathrm{NaCl}, \mathrm{HCl}$ and ethyl acetate were all reagent grade, which were obtained from Aladdin Reagent, Ltd.

\section{By-products recovery process}

CMC wastewater with ethanol was distilled under vacuum $(<2 \mathrm{kPa})$ at different temperatures $\left(45-70{ }^{\circ} \mathrm{C}\right)$. Initial $\mathrm{pH}$ of wastewater was adjusted to different values $(6.5,8.5$, $9.5,10.5,12.0)$ before distillation to study the effect of $\mathrm{pH}$ on by-products in wastewater. The solid residue after distillation was washed using concentrated $\mathrm{HCl}(35-38 \%)$ to dissolve out organic by-products adsorbed. The $\mathrm{HCl}$-containing liquid phase was then separated from solid phase by centrifugation. The white solid obtained, i.e., inorganic by-products, was dried at $110{ }^{\circ} \mathrm{C}$ for powder XRD analysis with $\mathrm{Cu} \mathrm{K}_{\alpha 1}$, graphite monochromator and Lynxeye detector (Bruker D2 Phaser, Germany) and TGA analysis with a $10 \mathrm{~K} \mathrm{~min}^{-1}$ heating rate under nitrogen (Linseis STA PT1000, Germany). The $\mathrm{HCl}$-containing liquid phase was mixed with ethyl acetate and shaken 30 minutes in endover-end manner at $26 \mathrm{rpm}$ and $20 \pm 1{ }^{\circ} \mathrm{C}$ to extract organic compounds. Volume ratio of liquid phase to ethyl acetate was $1: 5$. The same extraction process was conducted three times and then organic phase was separated, dehydrated and distilled under vacuum $(<2 \mathrm{kPa})$ at $40-70{ }^{\circ} \mathrm{C}$ (Fig. 2). The liquid residues in the distillation flask, i.e., organic by-products, were taken for NMR (Bruker Avance III $400 \mathrm{MHz}$, Germany) and gas chromatography-mass spectrum (GC-MS, Shimadzu QP-2010Ultra, Japan) analysis. The capillary column used was Rtx-5MS (30.0 $\mathrm{m} \times 0.25 \mathrm{~mm} \times 0.25 \mu \mathrm{m})$. The initial oven temperature was $60{ }^{\circ} \mathrm{C}$ for 4 minutes, ramped to $140{ }^{\circ} \mathrm{C}$ for 2 minutes, then to $280{ }^{\circ} \mathrm{C}$ at $2{ }^{\circ} \mathrm{C} \mathrm{min}{ }^{-1}$ for 30 minutes. Helium was used as a carrier gas at $0.6 \mathrm{ml} \mathrm{min}^{-1}$.

\section{Biological treatment process}

Since the distillate from distillation contained some dissolved organic compounds and still had high COD, it was important to treat the distillate by biological method. In this study, the distillate collected was imported into adjusting tank and mixed with domestic sewage and flushing water 
from manufacturing shop to form a combined wastewater $(\mathrm{CW})$. The $\mathrm{COD}_{\mathrm{Cr}} \mathrm{BOD}_{5}$, volume fraction of three kinds of wastewater are listed in Table 1. The final $\mathrm{pH}$ of $\mathrm{CW}$ was adjusted to a range from 6.0 to 8.0. Then, CW was imported into UASB reactors where $\mathrm{CW}$ was allowed to stay $72 \mathrm{hrs}$ for anaerobic reaction. UASB may promote sludge concentration in reactors and thus enhance treatment efficiency of wastewater. The anaerobic effluent was imported into the aerobic tank where biological contact oxidation process was adopted for aerobic degradation of CW. Hy- draulic residence time (HRT) in aerobic tank was $28 \mathrm{hrs}$. Contact oxidation process has a high volume loading and good resistance to shock loading, which is appropriate to treat the wastewater in this study. The aerobic effluent was imported into the sedimentation tank for clarification and then discharged. All granular sludge was taken from Shanghai Songdong Purify Water Environment Co. Ltd., and inoculated to anaerobic and aerobic tanks at the beginning of operation. Experimental temperature was $25 \pm 5{ }^{\circ} \mathrm{C}$. $\mathrm{CW}$ treatment process is shown in Fig. 3.

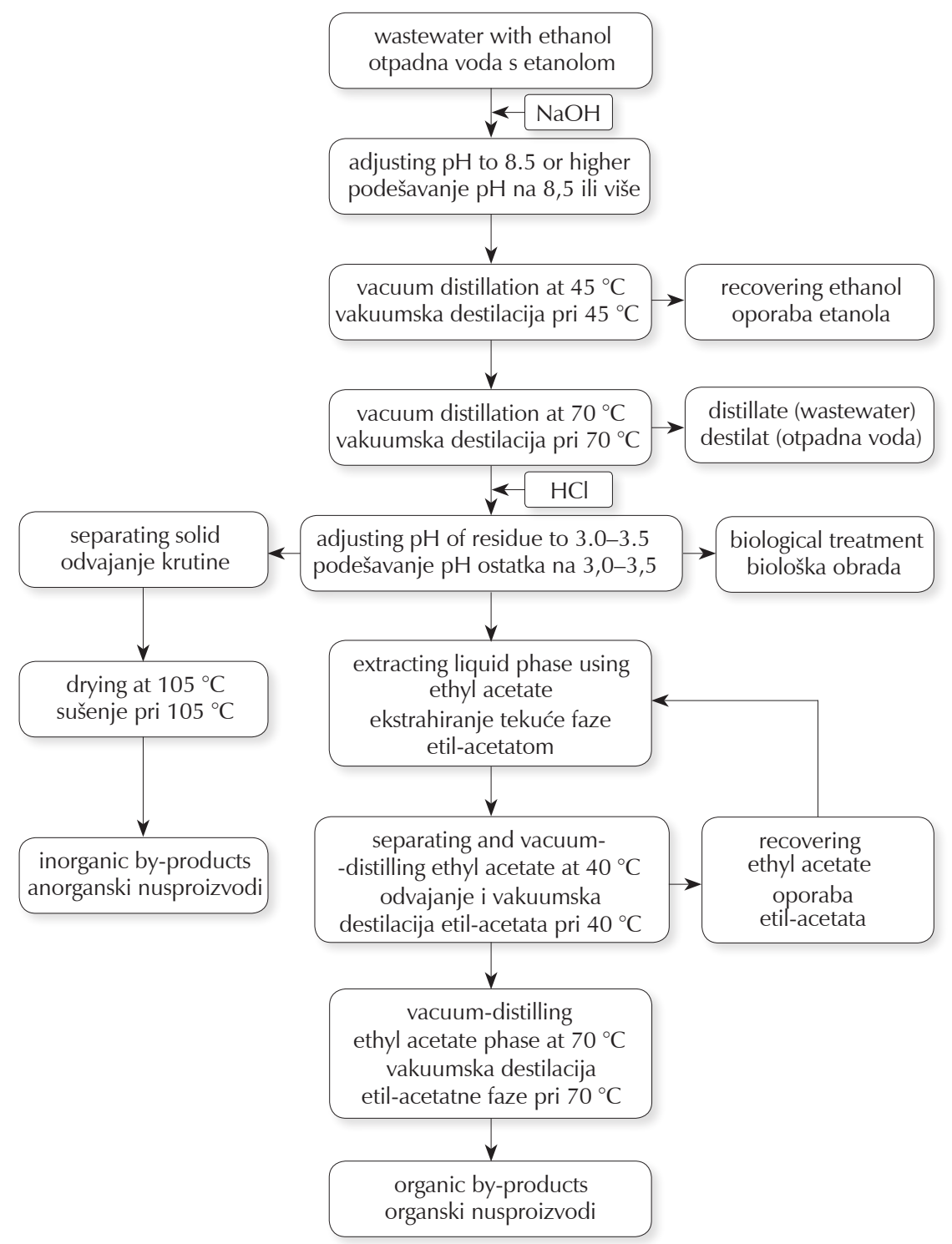

Fig. 2 - By-products recovery process

Slika 2 - Proces oporabe nusproizvoda

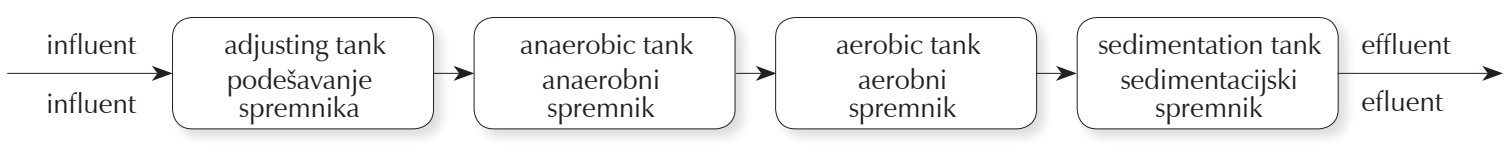

Fig. 3 - Treatment process of combined wastewater Slika 3 - Proces obrade kombiniranih otpadnih voda 
Table 1 - Composition and properties of combined wastewater for biological treatment

Tablica 1 - Sastav i svojstva kombiniranih otpadnih voda za biološku obradu

\begin{tabular}{l|c|c|c}
\hline $\begin{array}{l}\text { Wastewater type } \\
\text { Vrsta otpadne } \\
\text { vode }\end{array}$ & $\mathrm{COD}_{\mathrm{Cr}} / \mathrm{mgl}^{-1}$ & $\mathrm{BOD}_{5} / \mathrm{mgl}^{-1}$ & $\begin{array}{c}\text { Volume } \\
\text { fraction } \\
\text { Obujamski } \\
\text { udjel }\end{array}$ \\
\hline $\begin{array}{l}\text { distillate } \\
\text { destilat }\end{array}$ & $6336-16288$ & $1810-3800$ & 0.4 \\
$\begin{array}{l}\text { domestic sewage } \\
\text { otpadna voda iz } \\
\text { kućanstva }\end{array}$ & $272-243.2$ & - & 0.3 \\
$\begin{array}{l}\text { flushing water } \\
\text { voda za ispiranje }\end{array}$ & $406-606$ & $121-158$ & 0.3 \\
\hline
\end{tabular}

\section{Results and discussion}

\section{By-products recovery}

In the process of CMC production, large quantities of by-products including organic and inorganic compounds would form. In order to analyse the effect of $\mathrm{pH}$ on by-products, the initial $\mathrm{pH}$ of ethanol-containing CMC wastewater was adjusted to several different values $(6.5,8.5,9.5,10.5,12.0)$ before distillation.

As shown in Table 2, the $\mathrm{pH}$ significantly affected components in organic by-products extracted from CMC wastewater. At $\mathrm{pH}$ 6.5, more than ten compounds were identified. 1,3-diethoxy-2-propanol (CAS 4043-59-8) was dominant with the content of $41.25 \%$, possibly resulting from polycondensation of multiple compounds. Howev-

Table 2 - Components in by-products detected by GC-MS

Tablica 2 - Komponente u nusproizvodima otkrivene pomoću GC-MS

\begin{tabular}{|c|c|c|c|}
\hline $\mathrm{pH}$ & $\begin{array}{c}\text { Time / min } \\
\text { Vrijeme/min }\end{array}$ & $\begin{array}{c}\text { Area } / \% \\
\text { Područje/\% }\end{array}$ & $\begin{array}{l}\text { CAS No. } \\
\text { CAS-broj }\end{array}$ \\
\hline \multirow{18}{*}{6.5} & 8.53 & 41.25 & $4043-59-8$ \\
\hline & 14.717 & 7.32 & $84-66-2$ \\
\hline & 14.813 & 0.49 & $3782-85-2$ \\
\hline & 15.792 & 9.3 & $947-19-3$ \\
\hline & 15.855 & 1.02 & 42978-66-5 \\
\hline & 15.949 & 2.23 & 42978-66-5 \\
\hline & 16.05 & 2.19 & $541-1-5$ \\
\hline & 16.706 & 3.27 & 16397-66-3 \\
\hline & 16.905 & 2.91 & $84-69-5$ \\
\hline & 17.148 & 2.4 & $541-1-5$ \\
\hline & 17.617 & 12.31 & $84-74-2$ \\
\hline & 18.143 & 3.43 & $541-1-5$ \\
\hline & 18.732 & 0.89 & $206-44-0$ \\
\hline & 19.038 & 3.32 & 541-1-5 \\
\hline & 19.937 & 2.91 & $541-1-5$ \\
\hline & 20.944 & 2.11 & $541-1-5$ \\
\hline & 22.151 & 1.48 & $541-1-5$ \\
\hline & 23.658 & 1.17 & $541-1-5$ \\
\hline \multirow{6}{*}{8.5} & 3.495 & 4.92 & $64-19-7$ \\
\hline & 5.585 & 1.17 & $541-5-9$ \\
\hline & 6.055 & 8.37 & $629-14-1$ \\
\hline & 7.25 & 2.39 & 817-95-8 \\
\hline & 8.095 & 0.31 & $556-67-2$ \\
\hline & 9.315 & 82.84 & $627-3-2$ \\
\hline \multirow{5}{*}{9.5} & 3.2 & 1.61 & $64-19-7$ \\
\hline & 7.565 & 2.37 & $817-95-8$ \\
\hline & 9.145 & 89.12 & $627-3-2$ \\
\hline & 11.835 & 0.61 & $0-0-0$ \\
\hline & 13.655 & 6.29 & $817-95-8$ \\
\hline \multirow{3}{*}{10.5} & 3.11 & 1.76 & $64-19-7$ \\
\hline & 7.31 & 6.61 & $817-95-8$ \\
\hline & 9.295 & 91.63 & $627-3-2$ \\
\hline \multirow{3}{*}{12.0} & 2.295 & 0.7 & $141-78-6$ \\
\hline & 6.965 & 0.22 & 817-95-8 \\
\hline & 8.355 & 99.08 & $627-3-2$ \\
\hline
\end{tabular}


er, when $\mathrm{pH}$ of wastewater was elevated to 8.5 , another chemical compound ethoxyacetic acid (CAS 627-3-2) was found to be dominant with the content of $82.84 \%$. Moreover, percentage of ethoxyacetic acid increased significantly with the increase of initial $\mathrm{pH}$ of $\mathrm{CMC}$ wastewater. When $\mathrm{pH}$ was adjusted to 12.0 , percentage of ethoxyacetic acid reached $99.08 \%$, which indicated that recovery of by-products from CMC wastewater was feasible.

Fig. 4 shows the ${ }^{1} \mathrm{H}$ NMR $\left(\mathrm{CDCl}_{3}\right)$ spectrum of organic by-products. Four main chemical shifts were found. The chemical shifts at about $1.2 \mathrm{ppm}\left(\mathrm{CH}_{3}\right)$ and $3.6 \mathrm{ppm}\left(\mathrm{CH}_{2}\right)$ were assigned to ethyl bonded to $\mathrm{O}$. The chemical shift at about 4.1 was assigned to the other $\mathrm{CH}_{2}$. The chemical shift at about $8.2 \mathrm{ppm}$ could be assigned to the $\mathrm{OH}$ of carboxylic acid. The chemical shifts above confirmed that organic by-product extracted from CMC wastewater was mainly ethoxyacetic acid.

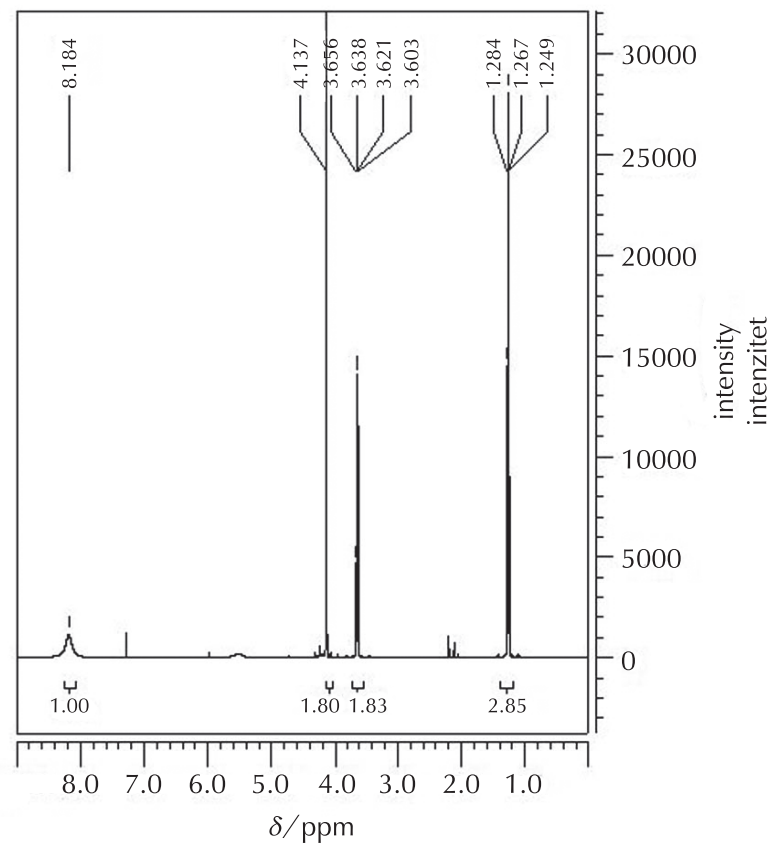

Fig. $4-{ }^{1} \mathrm{H}$ NMR spectrum of organic by-products Slika 4 - ${ }^{1} \mathrm{H}$ NMR-spektar organskih nusproizvoda

According to organic components in by-products, possible main reaction equations were written as follows.

$$
\begin{aligned}
& \mathrm{ClCH}_{2} \mathrm{COOH}+\mathrm{CH}_{3} \mathrm{CH}_{2} \mathrm{OH}+\mathrm{NaOH} \rightarrow \\
& \rightarrow \mathrm{CH}_{3} \mathrm{CH}_{2} \mathrm{OCH}_{2} \mathrm{COOH}+\mathrm{NaCl}+\mathrm{H}_{2} \mathrm{O} \\
& \mathrm{ClCH}_{2} \mathrm{COOH}+\mathrm{CH}_{3} \mathrm{CH}_{2} \mathrm{OH}+2 \mathrm{NaOH} \rightarrow \\
& \rightarrow \mathrm{CH}_{3} \mathrm{CH}_{2} \mathrm{OCH}_{2} \mathrm{COONa}+\mathrm{NaCl}+2 \mathrm{H}_{2} \mathrm{O} \\
& \underset{\mathrm{CH}_{3} \mathrm{CH}_{2} \mathrm{OCH}_{2} \mathrm{COONa}+\mathrm{HCl} \rightarrow}{\rightarrow \mathrm{CH}_{3} \mathrm{CH}_{2} \mathrm{OCH}_{2} \mathrm{COOH}+\mathrm{NaCl}}
\end{aligned}
$$

It is obvious that, under alkaline conditions, ethoxyacetic acid would be neutralized by $\mathrm{NaOH}$, resulting in the formation of sodium ethoxyacetate. According to Fig. 2, CMC wastewater with ethanol was vacuum-distilled at
$70{ }^{\circ} \mathrm{C}$ to remove ethanol and water. Sodium ethoxyacetate has better chemical stability than ethoxyacetic acid, which avoided further reaction of ethoxyacetic acid by polycondensation or other pathways under heating. Higher $\mathrm{pH}$ environment would result in the formation of more sodium ethoxyacetate, thus causing the higher percentage of ethoxyacetic acid according to Eq. (1), (2) and (3).

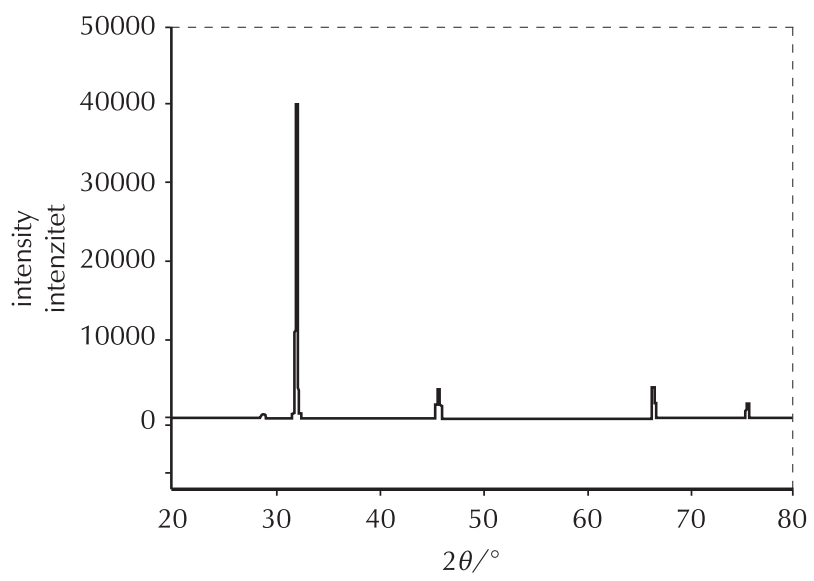

Fig. 5 - XRD pattern of solid by-products

Slika 5 - Rendgenski difraktogram čvrstih nusproizvoda

Fig. 5 shows the XRD pattern of inorganic by-products. Four typical peaks $\left(2 \theta=31.8^{\circ}, 45.5^{\circ}, 66.3^{\circ}, 75.4^{\circ}\right)$ were observed, corresponding with the characteristic peaks of $\mathrm{NaCl}$ ((200), (220), (400), (420)), which indicated that the inorganic by-products obtained mainly contained $\mathrm{NaCl}^{12}$

The thermal behaviour of inorganic by-products was examined by TGA. According to Fig. 6, the inorganics in the solid was about $96 \%$, which indicated that high purity $\mathrm{NaCl}$ was obtained. Besides, two stages of the thermal degradation of the solid were observed. The first stage, i.e., the mass loss below $150{ }^{\circ} \mathrm{C}$, should be attributed to evaporation of $\mathrm{H}_{2} \mathrm{O}$. The second stage, i.e., the mass loss above $220^{\circ} \mathrm{C}$, was ascribed to degradation of the organics, indicating the existence of a small quantity of organics in inorganic by-products.

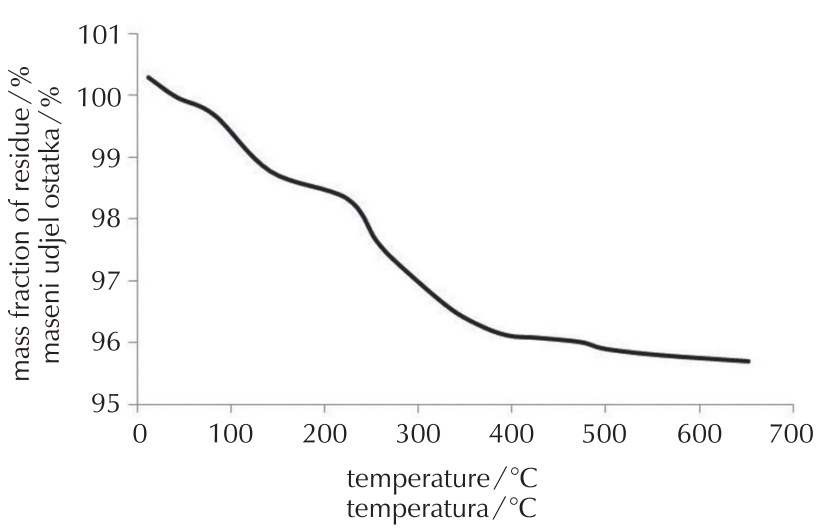

Fig. 6 - TGA curve of solid by-products

Slika 6 - Termogravimetrijska krivulja čvrstih nusproizvoda 


\section{Wastewater biological treatment}

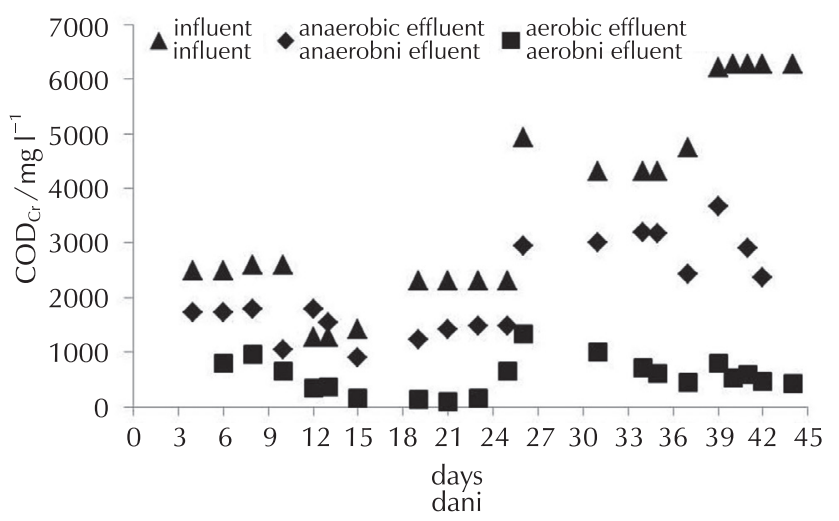

Fig. $7-\mathrm{COD}_{\mathrm{Cr}}$ changes of combined wastewater $(\mathrm{CW})$ in the treatment process

Slika 7 - Promjene u $\mathrm{COD}_{\mathrm{Cr}}$ kombiniranih otpadnih voda $(\mathrm{CW})$ u procesu obrade

As shown in Fig. 7, the $\mathrm{COD}_{\mathrm{Cr}}$ of influent $\mathrm{CW}$ changed from 2100 to $6500 \mathrm{mg} \mathrm{l}^{-1}$, indicating the relatively great $\mathrm{COD}_{\mathrm{Cr}}$ fluctuation. The results of 45-day continuous operation show that the treatment process used had a good resistance to shock loading. The $\mathrm{COD}_{\mathrm{Cr}}$ of anaerobic effluent was between 1000 and $4000 \mathrm{mgl}^{-1}$. The $\mathrm{COD}_{\mathrm{Cr}}$ of aerobic effluent after 45-day operation was below $500 \mathrm{mg} \mathrm{l}^{-1}$ which met Shanghai Industrial Wastewater Discharge Standard (COD $<500 \mathrm{mg} \mathrm{l}^{-1}$ ) and indicated the treatment process in this study was feasible.

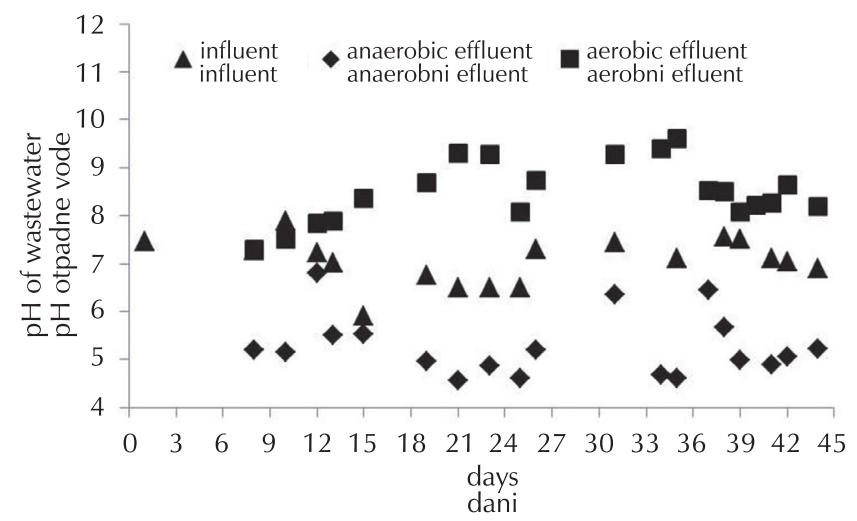

Fig. 8 - pH changes of $\mathrm{CW}$ in the treatment process Slika 8 - Promjene $\mathrm{pH}$ otpadnih voda u procesu obrade

The $\mathrm{pH}$ changes in the wastewater treatment process can provide significant information with regard to biological states. Fig. 8 shows the changes of $\mathrm{pH}$ of influent and effluent $\mathrm{CW}$ in the treatment process. The $\mathrm{pH}$ of influent $\mathrm{CW}$ was at a range from 6.0 to 8.0. In comparison, the $\mathrm{pH}$ of anaerobic effluent decreased, which could result from hydrolysis and acidification of organic pollutants in the wastewater under the action of anaerobic bacteria. ${ }^{13}$ However, $\mathrm{pH}$ of aerobic effluent significantly ascended and maintained a range from 7 to 9.5, possibly due to degradation of organic acid and nitrification of ammonium nitrogen in wastewater. ${ }^{14}$

\section{Conclusion}

In this paper, distillation-extraction method was used to pretreat CMC wastewater. By-products including ethoxyacetic acid and $\mathrm{NaCl}$ in wastewater were recovered and identified by NMR and XRD. Initial pH of CMC wastewater was found to affect significantly the purity of ethoxyacetic acid in organic by-products. A relatively high purity (96\%) of $\mathrm{NaCl}$ was recovered from $\mathrm{CMC}$ wastewater. UASB-contact oxidation process was employed to treat distillate from CMC wastewater distillation and showed good resistance to shock loading. Results of 45-day continuous operation show that $\mathrm{COD}_{\mathrm{Cr}}$ of final effluent might be controlled below $500 \mathrm{mg} \mathrm{l}^{-1}$, which indicates that the treatment process in this study was appropriate to treat wastewater from $\mathrm{CMC}$ production industry.

\section{ACKNOWLEDGEMENTS}

This work is supported by Innovation Projects from Shanghai Municipal Education Committee (12YZ153), Program for Training Young Teachers in Colleges and Universities in Shanghai City (ZZGJD12052) and the State Key Laboratory of Pollution Control and Resource Reuse Foundation (PCRRF12019).

\section{List of symbols and abbreviations Popis simbola i kratica}

$\delta \quad-$ chemical shift, ppm

- kemijski pomak, ppm

$\theta \quad-$ Bragg angle, ${ }^{\circ}$

- Braggov kut,

$\mathrm{BOD}_{5}$ - biochemical oxygen demand, $\mathrm{mgl}^{-1}$

- biokemijska potreba za kisikom, $\mathrm{mgl}^{-1}$

CMC - carboxymethyl cellulose

- karboksimetil-celuloza

COD - chemical oxygen demand, $\mathrm{mg}^{-1}$

- kemijska potreba za kisikom, $\mathrm{mgl}^{-1}$

$\mathrm{COD}_{\mathrm{Cr}}$ - chromate determined chemical oxygen demand, $\mathrm{mgl}^{-1}$

- kemijska potreba za kisikom određena kromatom, $\mathrm{mgl}^{-1}$

CW - combined wastewater

- kombinirana otpadna voda

HPC - hydroxypropyl cellulose

- hidroksipropil-celuloza

HPMC - hydroxypropyl methyl cellulose

- hidroksipropil-metil-celuloza

HRT - hydraulic residence time

- hidrauličko vrijeme zadržavanja

MC - methyl cellulose

- metil-celuloza

MEC - ethyl methyl cellulose

- etil-metil-celuloza

SMCA - sodium monochloroacetate

- natrijev monokloracetat

TGA - thermogravimetric analysis

- termogravimetrijska analiza

UASB - upflow anaerobic sludge blanket

- reaktor s lebdećim muljem 


\section{References \\ Literatura}

1. A. M. Bochek, I. L. Shevchuk, L. M. Kalyuzhnaya, Properties of blends of methyl cellulose and carboxymethyl cellulose with different degrees of ionization in solutions and solids, Russ. J. Appl. Chem. 81 (2008) 691-695, doi: http://dx.doi. org/10.1134/S1070427208040241.

2. V. Pushpamalar, S. J. Langford, M. Ahmad, Y. Y. Lim, Optimization of reaction conditions for preparing carboxymethylcellulose from sago waste, Carbohyd. Polym. 64 (2006) 312318, doi: http://dx.doi.org/10.1016/j.carbpol.2005.12.003.

3. P. Methacanon, O. Chaikumpollert, P. Thavorniti, K. Suchiva, Hemicellulosic polymer from vetiver grass and its physicochemical properties, Carbohyd. Polym. 54 (2003) 335-342, doi: http://dx.doi.org/10.1016/S0144-8617(03)00182-6.

4. C. J. Tijsen, H. J. Kolk, E. J. Stamhuis, A. A. C. M. Beenackers, An experimental study on the carboxymethylation of granular potato starch in non-aqueous media, Carbohyd. Polym. 45 (2001) 219-226, doi: http://dx.doi.org/10.1016/S01448617(00)00243-5.

5. O. Dahlman, A. Jacobs, J. Sjoberg, Molecular properties of hemicelluloses located in the surface and inner layers of hardwood and softwood pulps, Cellulose 10 (2003) 325334, doi: http://dx.doi.org/10.1023/A:1027316926308.

6. A. Pak, T. Mohammadi, Wastewater treatment of desalting units, Desalination 222 (2008) 249-254, doi: http://dx.doi. org/10.1016/j.desal.2007.01.166.

7. W. Han, L. Wang, X. Sun, J. Li, Treatment of bactericide wastewater by combined process chemical coagulation, electrochemical oxidation and membrane bioreactor, J. Hazard. Mater. 151 (2008) 306-315, doi: http://dx.doi. org/10.1016/j.jhazmat.2007.05.088.
8. Y. Kim, B.E. Logan, Simultaneous removal of organic matter and salt ions from saline wastewater in bioelectrochemical systems, Desalination 308 (2013) 115-121, doi: http://dx. doi.org/10.1016/j.desal.2012.07.031.

9. H. Park, K. Choo, H. Park, J. Choi, M.R Hoffmann, Electrochemical oxidation and microfiltration of municipal wastewater with simultaneous hydrogen production: influence of organic and particulate matter, Chem. Eng. J. 215-216 (2013) 802-810, doi: http://dx.doi.org/10.1016/j.cej.2012.11.075.

10. M. Zhou, L. Liu, Y. Jiao, Q. Wang, Q. Tan, Treatment of high-salinity reverse osmosis concentrate by electrochemical oxidation on BDD and DSA electrodes, Desalination 227 (2011) 201-206, doi: http://dx.doi.org/10.1016/j.desal.2011.04.030

11. D. Zhao, J. Xue, S. Li, H. Sun, Q. Zhang, Theoretical analyses of thermal and economical aspects of multi-effect distillation desalination dealing with high-salinity wastewater, Desalination 273 (2011) 292-298, doi: http://dx.doi.org/10.1016/j. desal.2011.01.048.

12. K. Linnow, H. Juling, M. Steiger, Investigation of $\mathrm{NaCl}$ deliquescence in porous substrates using RH-XRD, Environ. Geol. 52 (2007) 317-327, doi: http://dx.doi.org/10.1007/ s00254-006-0590-9.

13. C. P. L. Grady, G. T. Daigger, H. C. Lim, Biological Wastewater Treatment, $2^{\text {nd }}$ ed., Marcel Dekker, New York, 1999, pp. 261-632.

14. H. M. Jang, J. W. Lee, J. H. Ha, J. M. Park, Effect of organic loading rates on rates on reactor performance and microbial community changes during thermophilic aerobic digestion process of high-strength food wastewater, Bioresource Technol. 148 (2013) 261-269, doi: http://dx.doi.org/10.1016/j. biortech.2013.08.090. 


\title{
SAŽETAK
}

\section{Oporaba kemijskih spojeva pri pročišćavanju otpadnih voda s karboksimetil-celulozom}

\author{
Pinhua Rao, Wenqi Zhang, a* Wei Yao, ${ }^{a}$ Aiyun Zhu, ${ }^{a}$ \\ Jueliang Xia, ${ }^{a}$ Yifan Tan, ${ }^{a}$ Yingjie Lia i Tongzhou Liu
}

Otpadne vode s karboksimetil-celulozom (CMC) obično imaju visoku kemijsku potrebu za kisikom (COD) i salinitet (>10\%). Prije primjene biokemijskih metoda važno je otpadne vode pročistiti radi smanjenja saliniteta i oporabe vrijednih spojeva. U ovom je radu otpadna voda s CMC-om predobrađena destilacijom i ekstrakcijom. Iz otpadne vode izvučeni su vrijedni kemijski spojevi uključujući etoksioctenu kiselinu i NaCl. Analize metodama GC-MS i NMR pokazuju da čistoća etoksioctene kiseline raste s povećanjem početnog $\mathrm{pH}$ otpadne vode. Primijenjen je anaerobno-aerobni postupak za pročišćavanje destilata (reaktor s lebdećim muljem i kontaktna oksidacija), koji je pokazao dobru otpornost na udarna opterećenja.

Nakon 45-dnevnog kontinuiranog rada $\mathrm{COD}_{\mathrm{Cr}}$ se može održati ispod $500 \mathrm{mg} \mathrm{I}^{-1}$ što je u skladu sa šangajskim standardima za ispuštanje industrijskih otpadnih voda.

\section{Ključne riječi}

Etoksioctena kiselina, karboksimetil-celuloza, pročišćavanje otpadnih voda, oporaba

\author{
${ }^{a}$ School of Chemistry and Chemical Engineering \\ Shanghai University of Engineering Science \\ Shanghai 201620 \\ Kina \\ ${ }^{\mathrm{b}}$ Harbin Institute of Technology \\ Shenzhen Graduate School \\ Shenzhen 518055 \\ Kina
}

Izvorni znanstveni rad Prispjelo 18. ožujka 2014. Prihvaćeno 24. rujna 2014. 